\title{
Analisis Strategi Pemasaran Telur Itik di Desa Teluk Baru Kecamatan Amuntai Selatan Kabupaten Hulu Sungai Utara Propinsi Kalimantan Selatan
}

\section{(Marketing Strategy Analysis of Duck Eggs in The Teluk Baru Village Amuntai Selatan District Hulu Sungai Utara Regency Kalimantan Selatan)}

\author{
Arief Hidayatullah' ${ }^{1}$, Purna Kusumayana \& Munatun Najah \\ Program Studi Agribisnis, Sekolah Tinggi Ilmu Pertanian Amuntai \\ ${ }^{1}$ arief_stiperamuntai @yahoo.com
}

\begin{abstract}
ABSTRAK
Penelitian ini bertujuan untuk mengetahui kekuatan, kelemahan, peluang dan ancaman dalam pemasaran telur itik di Desa Teluk Baru Kecamatan Amuntai Selatan Kabupaten Hulu Sungai Utara Provinsi Kalimantan Selatan. Hasil penelitian yang dilakukan di Desa Teluk Baru Kecamatan Amuntai Selatan Kabupaten Hulu Sungai Utara Provinsi Kalimantan Selatan untuk pemasaran telur itik menggunakan strategi formulasi dan seleksi didasarkan pada analisis lingkungan internal dan eksternal menggunakan matriks IFE dan EFE, nilai-nilai yang diperoleh dari analisis faktor eksternal (EFE) sebesar 2,967, dan untuk nilai analisis faktor internal (IFE) sebesar 2,98. Dapat disimpulkan bahwa pemasaran telur itik di Hulu Sungai Utara yaitu sedang. Pemasaran penempatan telur itik ada dalam sel V dengan strategi untuk memegang dan memelihara. Jenis strategi utama yang dapat diterapkan adalah strategi intensif, strategi penetrasi pasar, pengembangan produk.
\end{abstract}

Kata kunci: Analisis, strategi, pemasaran, telur, itik.

\begin{abstract}
This study aims to determine the strengths, weaknesses, opportunities and threats in the marketing of duck eggs in the Teluk Baru Village Amuntai Selatan Kabupaten Hulu Sungai Utara Regency Kalimantan Selatan Province. Results of research conducted in the Teluk Baru Kecamatan Amuntai Selatan District Hulu Sungai Utara Regency Kalimantan Selatan Provinve to the marketing of duck eggs using the formulation and selection strategy is based on the analysis of internal and external environments using IFE and EFE matrix, the values obtained from the analysis of external factors (EFE) of 2.967, and for the value of the analysis of internal factors (IFE) of 2.98. It can be concluded that the marketing of duck eggs in North Hulu Sungai is medium. Marketing the placement of duck eggs is in cell V with a strategy to hold and maintain. The main types of strategies that can be applied are intensive strategies, market penetration strategies, product development.
\end{abstract}

Keywords: Analysis, strategy, marketing, eggs, duck.

\section{PENDAHULUAN}

Indonesia merupakan salah satu negara yang menjadikan sektor peternakan yang menjadikan sandaran perekonomian dan memiliki kontribusi yang cukup besar dalam pencapaian tujuan pembangunan perekonomian. Namun, hal ini belum digunakan secara optimal. Telur itik akan memberikan nilai tambah kalau diolah atau digunakan sebagai pelengkap dalam olahan makanan.

Salah satu desa penghasil telur itik konsumsi adalah Desa Teluk Baru yang ada di Kecamatan Amuntai Selatan. Pemasaran telur itik disana hanya menjual ke pasar Alabio, pasar Telaga Silaba, dan lain-lain atau pembeli yang datang langsung kepeternak di Desa Teluk Baru untuk dipasarkan kembali ke daerah lain. 
Tabel 1. Perkembangan produksi telur itik di Desa Teluk Baru

\begin{tabular}{ccc}
\hline No & Bulan & Jumlah Produksi \\
\hline 1 & Januari & 8.470 \\
2 & Pebruari & 13.225 \\
3 & Maret & 21.362 \\
4 & April & 15.645 \\
5 & Mei & 18.553 \\
6 & Juni & 18.663 \\
7 & Juli & 18.672 \\
8 & Agustus & 18.237 \\
9 & September & 17.915
\end{tabular}

Sumber: Anonim, 2011

Penelitian ini bertujuan (i) melakukan analisis SWOT untuk mengetahui kekuatan dan kelemahan serta ancaman dan peluang usaha telur itik Kelompok Tani"Harapan Kita" di Desa Teluk Baru Kecamatan Amuntai Selatan Kabupaten Hulu Sungai
Utara Propinsi Kalimantan Selatan, dan (ii) mengetahui bagaimana strategi pemasaran telur itik Kelompok Tani "Harapan Kita" di Desa Teluk Baru Kecamatan Amuntai Selatan Kabupaten Hulu Sungai Utara Propinsi Kalimantan Selatan.

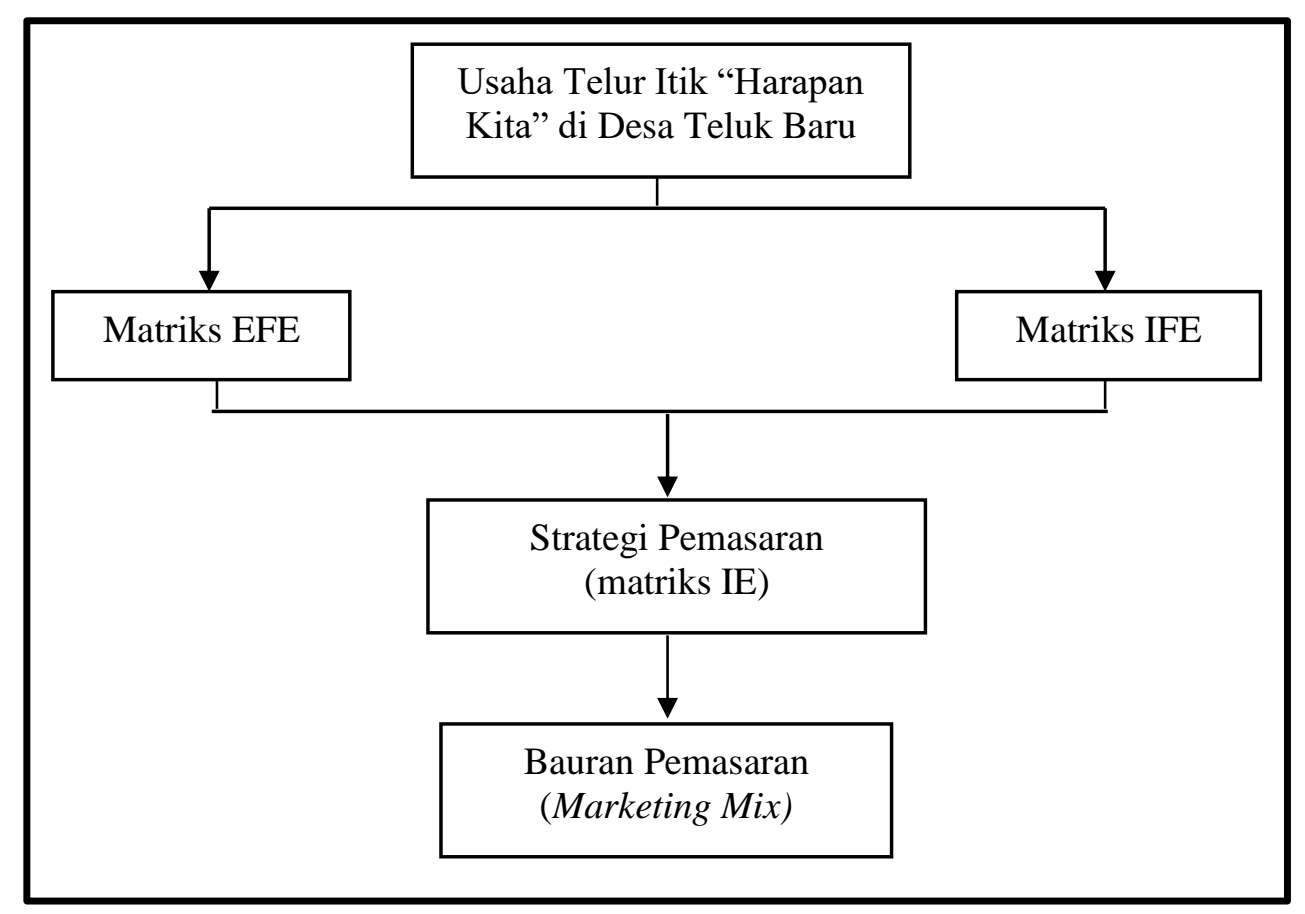

Gambar 1. Kerangka Pemikiran Teoritis

\section{METODE PENELITIAN}

Tempat dan Waktu Penelitian

Penelitian dilaksanakan di Desa Teluk Baru Kecamatan Amuntai Selatan Kabupaten Hulu Sungai Utara Propinsi
Kalimantan Selatan. Penelitian dilakukan dimulai bulan Mei - September 2012.

\section{Jenis dan Sumber Data}

Data yang dikumpulkan berupa data primer dan data sekunder. Data primer diperoleh dari wawancara langsung dengan 
responden dan data sekunder diperoleh dari instansi-instansi yang terkait.

\section{Metode Pengumpulan Data}

Metode pengumpulan data yang digunakan dalam penelitian ini adalah metode sensus dimana semua anggota populasi dijadikan sampel. Penelitian ini merupakan penelitian deskriptif kualitatif. Data diperoleh dari wawancara kepada responden dengan menggunakan daftar pertanyaan.

Penelitian ini responden yang dipilih dengan sengaja. Responden terdiri dari pihak internal dan eksternal. Pihak internal yaitu peternak telur itik di Desa Teluk Baru, sedangkan pihak eksternal yaitu Dinas Peternakan dan Pedagang.

\section{HASIL DAN PEMBAHASAN}

Berdasarkan dari hasil analisis faktor internal dan eksternal pada usaha telur itik yang ada di Desa Teluk Baru, maka dapat diidentifikasi kekuatan dan kelemahan serta peluang dan ancaman terhadap pemasaran telur itik.

Identifikasi faktor internal:

Kekuatan

1. Memakai tenaga kerja dalam keluarga

2. Lokasi pemasaran yang tersedia
3. Distribusi produk cukup luas

4. Produk sesuai selera konsumen

5. Harga produk terjangkau

$\underline{\text { Kelemahan }}$

1. Tidak adanya visi dan misi secara tertulis

2. Sistem manajemen sederhana

3. Kualitas SDM rendah

4. Kurangnya penggunaan teknologi (internet) informasi untuk mengetahui harga pasar

5. Tidak adanya pencatatan laporan keuangan

Identifikasi faktor eksternal:

Peluang

1. Dukungan pemerintah dalam pengembangan pemasaran telur itik alabio di Kabupaten Hulu Sungai Utara

2. Keadaan ekonomi yang membaik

3. Pola konsumsi masyarakat bahwa telur itik kaya akan vitamin

4. Produk yang mudah didapat

5. Produk yang tersedia masih kurang sehingga tidak menyebabkan tawarmenawar antara produsen dan konsumen $\underline{\text { Ancaman }}$

1. Kenaikan harga BBM

2. Ancaman pesaing dengan produk yang sama

3. Produk subtitusi

4. Semakin kuatnya pesaing dengan produk subtitusi

5. Penyakit yang menyerang

\section{Matriks EFE dan IFE}

Tabel 2. Matriks EFE usaha telur itik di Desa Teluk Baru

\begin{tabular}{llll}
\hline Faktor-faktor Kunci & Bobot & Rating & bobot x ranting \\
\hline Peluang: & & & \\
\hline $\begin{array}{l}\text { 1. Dukungan pemerintah dalam pengembangan } \\
\text { pemasaran telur itik alabio di Kabupaten Hulu } \\
\text { Sungai Utara }\end{array}$ & 0,111 & 4 & 0,488 \\
\hline $\begin{array}{l}\text { 2. Keadaan perekonomian yang semakin membaik } \\
\begin{array}{l}\text { 3. Pola konsumsi masyarakat bahwa telur itik kaya } \\
\text { akan vitamin }\end{array}\end{array}$ & 0,117 & 4 & 0,468 \\
$\begin{array}{l}\text { 4. Produk yang mudah di dapat } \\
\begin{array}{l}\text { 5. Produk yang tersedia masih kurang sehingga tidak } \\
\text { menyebabkan tawar-menawar antara produsen } \\
\text { dengan konsumen }\end{array}\end{array}$ & 0,128 & 4 & 0,468 \\
\hline $\begin{array}{l}\text { Ancaman : } \\
\text { 1. Kenaikan harga BBM }\end{array}$ & 0,078 & 1 & 0,468 \\
\hline
\end{tabular}




\begin{tabular}{llll}
\hline 2. Ancaman pesaing dengan produk yang sama & 0,078 & 2 & 0,156 \\
\hline 3. Produk subtitusi & 0,094 & 2 & 0,188 \\
\hline 4. Semakin kuatnya pesaing dengan produk subtitusi & 0,094 & 2 & 0,188 \\
\hline 5. Penyakit yang menyerang & 0,089 & 1 & 0,094 \\
\hline Total & 1 & & 2,985
\end{tabular}

Tabel 3. Matriks IFE usaha telur itik di Desa Teluk Baru

Faktor-faktor Kunci

Kekuatan :

1. Memakai tenaga kerja dalam keluarga

2. Lokasi pemasarantersedia

3. Distribusi produk cukup luas

4. Kualitas produk baik

5. Harga produk terjangkau

Kelemahan :

1. Tidak adanya visi dan misi usaha

2. Sistem manajemen sederhana

3. Kualitas SDM rendah

4. Kurangnya penggunaan teknologi (internet) informasi untuk mengetahui harga pasar

5. Tidak adanya pencatatan laporan keuangan Total
Bobot

0,112

0,125

0,105

0,114

0.106

0,094

0,079

0,077

0,067

$0,056 \quad 2$

1

2

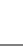

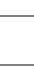

dalam matriks IE berada pada sel V. hal ini dapat dilihat pada Gambar 2.

Nilai total matriks EFE 2,985 dan matriks IFE 2,98 sehingga usaha telur itik

Total Nilai IFE yang Diberi Bobot

$\begin{array}{ccccc} & & \text { Kuat } & \text { Rata-rata } & \text { Lemah } \\ & & 3,0-4,0 & 2,0-2,99 & 1,0-1,99\end{array}$

Tinggi

$3,0-4,0$

Total Nilai EFE Yang Diberi Bobot

Rata-rata 2,985

2,0-2,99

$$
2,0
$$

Rendah

$$
1,0-2,0
$$

\begin{tabular}{|c|c|c|}
\hline $\begin{array}{c}\text { I } \\
\text { Tumbuh dan } \\
\text { Bina }\end{array}$ & $\begin{array}{c}\text { II } \\
\text { Tumbuh } \\
\text { dan bina }\end{array}$ & $\begin{array}{c}\text { III } \\
\text { Pertahankan } \\
\text { dan Pelihara }\end{array}$ \\
\hline $\begin{array}{c}\text { IV } \\
\text { Tumbuh dan } \\
\text { Bina }\end{array}$ & $\begin{array}{c}\text { Pertahankan } \\
\text { dan Pelihara }\end{array}$ & $\begin{array}{c}\text { VI } \\
\text { Panen dan } \\
\text { divestasi }\end{array}$ \\
\hline $\begin{array}{c}\text { VII } \\
\text { Pertahankan } \\
\text { dan Pelihara }\end{array}$ & $\begin{array}{c}\text { Panen dan } \\
\text { Divestasi }\end{array}$ & $\begin{array}{c}\text { Panen dan } \\
\text { Divestasi }\end{array}$ \\
\hline
\end{tabular}

Gambar 4. Posisi usaha telur itik pada Matriks IE 
Posisi ini disebut Hold and Maintain (jaga dan pertahankan). Strategi yang digunakan adalah strategi penetrasi pasar dan pengembangan produk (David, 2010).

\section{Bauran Pemasaran}

\section{$\underline{\text { Strategi Produk }}$}

Tingginya permintaan akan telur itik sedangkan jumlah atau produksi telur itik yang masih sedikit, maka diperlukan peningkan produksi baik itu kualitas maupun kuantitasnya. Memberikan pelayanan kepada pembeli yang ingin membeli telur itik dengan ramah untuk menjalin hubungan baik dengan pembeli atau pelanggan.

\section{Strategi Harga}

Terjadinya persaingan penjualan antara telur itik dengan telur subtitusi pada tingkat harga.Harga disesuaikan dengan daya beli konsumen dan bersaing dengan harga telur subtitusi tanpa mempengaruhi kualitasnya. Memberikan potongan kepada pelanggan tetap sehingga ini akan bisa meningkatkan pembeli sebagai pelanggan.

Strategi Distribusi

Peternak bisa menjalin kerja sama dengan pedagang untuk memperluas penjualan. Penjualan bisa keluar daerah dengan dilakukan kerja sama.

\section{$\underline{\text { Strategi Promosi }}$}

Meskipun telur itik adalah produk yang mudah untuk didapat, tetapi usaha ini juga memerlukan promosi untuk meningkatkan penjualan atau memperluas penjualan.Promosi yang dilakukan bisa dengan bicara dari mulut ke mulut, mengikuti pameran-pameran atau bisa juga dengan media elektronik.

\section{KESIMPULAN}

Berdasarkan hasil penelitian yang dilakukan terhadap pemasaran telur itik di Desa Teluk Baru Kabupaten Hulu Sungai Utara pada analisis lingkungan internal berada pada posisi rata-rata dalam pemanfaatan kekuatan dan kelemahannya. Kekuatan yang paling berpengaruh adalah pada lokasi pemasaran, sedangkan kelemahannya adalah kualitas SDM rendah. Peluang utama pada usaha telur itik diwilayah penelitian adalah produk yang tersedia masih kurang sehingga tidak menyebabkan tawar menawar antara produsen dengan konsumen, adapun yang menjadi ancaman utama adalah kenaikan BBM.

Berdasarkan analisis lingkungan eksternal maka diketahui hasil matriks EFE adalah 2,985 dan matriks IFE adalah 2,98, sehingga diperoleh pada matriks IE berada pada sel V yang menggambarkan Hold and Maintain (menjaga dan mempertahankan). Strategi yang tepat digunakan adalah strategi penetrasi pasar dan pengembangan produk.

Strategi pemasaran yang dapat digunakan pada usaha telur itik di Desa Teluk Baru adalah: 1) strategi produk berupa peningkatan jumlah telur itik sehingga volume penjualan juga akan meningkat dan peningkatan kualitas produk; 2) Strategi harga berupa harga penjualan yang sesuai dengan daya beli konsumen sehingga harga dapat bersaing dengan produk subtitusi tetapi kualitas telur tetap baik, menekan biaya pemeliharaan, memberikan potongan harga kepada pelanggan; 3) Strategi disribusi berupa menjalin kerja sama pada daerah luar baik itu kabupaten atau propinsi; 4) Strategi promosi berupa mempromosikan telur itik yang ada di Desa Teluk Baru dengan melalui media elektronik ataupun cetak.

\section{DAFTAR PUSTAKA}

Anonim. 2011. Profil Desa Teluk Baru. Kecamatan Amuntai Selatan. Kabupaten Hulu Sungai Utara.

David, Fred R. 2010. Manajemen Strategis. Selemba Empat. Jakarta.

Palmarudi Mappigau. 2011. Analisis strategi pemasaran telur pada peternakan ayam ras skala besar di Kabupaten Sidrap. Fakultas Peternakan Universitas Hasanudin.

Sunyoto, D. 2011. Metode Penelitian Ekonomi. Caps. Yogyakarta. 